\title{
CCR5 wt Allele
}

National Cancer Institute

\section{Source}

National Cancer Institute. CCR5 wt Allele. NCI Thesaurus. Code C51321.

Human CCR5 wild-type allele is located within 3p21 and is approximately $6 \mathrm{~kb}$ in length.

This allele, which encodes $\mathrm{C}-\mathrm{C}$ chemokine receptor type 5 protein, plays a role in

monocyte chemotaxis and G protein-coupled signal transduction. Defective alleles of this gene are associated with HIV infection resistance. 